\title{
National Survey on Curriculum of Speech-Language Pathology Programs in Korea
}

\author{
Hyun Rin Park ${ }^{\mathrm{a}}$, BoMyung Hwang ${ }^{\mathrm{b}}$, HyangHee Kim ${ }^{\mathrm{c}, \mathrm{d}}$, Son A Chang ${ }^{\mathrm{e}}$, Seong Hee Choi ${ }^{\mathrm{f}}$, Jaeock Kim ${ }^{\mathrm{g}}$, Hyo Jung Kim ${ }^{\mathrm{h}}$, \\ HeeJune Park ${ }^{i}$ \\ ${ }^{a}$ Department of Speech-Language Therapy, College of Health, Welfare E Education, Gwangju University, Gwangju, Korea \\ ${ }^{b}$ Department of Speech-Language Pathology, School of Health Science, Honam University, Gwangju, Korea \\ ${ }^{c}$ Graduate Program in Speech and Language Pathology, Yonsei University, Seoul, Korea \\ ${ }^{d}$ Department of Rehabilitation Medicine and Research Institute of Rehabilitation Medicine, Yonsei University College of Medicine, Seoul, Korea \\ ${ }^{e}$ Department of Otorhinolaryngology-Head and Neck Surgery, Seoul National University Hospital, Seoul, Korea \\ ${ }^{f}$ Department of Audiology E Speech-Language Pathology, College of Bio and Medical Sciences, Daegu Catholic University, Gyeongsan, Korea \\ ${ }^{8}$ Division of Speech Pathology Education, Graduate School of Education, Kangnam University, Yongin, Korea \\ ${ }^{h}$ Department of Speech-Language Pathology, College of Health and Welfare, Kosin University, Busan, Korea \\ iDepartment of Speech E Language Therapy, Choonhae College of Health Sciences, Ulsan, Korea
}

\author{
Correspondence: BoMyung Hwang, PhD \\ Department of Speech-Language Pathology, \\ School of Health Science, Honam University, \\ 417 Eodeung-daero, Gwangsan-gu, Gwangju \\ 62399, Korea \\ Tel: +82-62-940-5542 \\ Fax: +82-62-940-5046 \\ E-mail: slphwang@honam.ac.kr
}

Received: April 23, 2018

Revised: May 18, 2018

Accepted: May 24, 2018

This work was supported by funding for the Accreditation Project of the Korean Association of Speech-Language Pathologists (KSLP) and was partly presented at the 2017 Annual Meeting of the Korean Council of Academic Programs of Communication Disorders (KoCAPCD) held on November 4, 2017.
Objectives: Since 1988, when the Department of Speech-Language Pathology was first established at a university, a large number of speech-language pathologists (SLPS) have been trained. As of March 2018, there are 87 programs in 50 schools offering associate's degree, bachelor's degree, and/or master's/doctoral degree. In order to support the continued growth of the SLP programs, we believe it is necessary to assess the present operation status of all SLP programs. In this study, therefore, we surveyed the current curriculum of each program, and tried to lay out future direction that the SLP programs need to pursue. Methods: We sent out the questionnaires twice to all the programs. The questionnaires included the following: information about the program (e.g., number of faculty members), the status of the existing curriculum during the period of 2015-2017 academic years, and the curriculum improvement proposals from the program faculty members. After excluding the schools that did not respond or filled the questionnaire incorrectly, the contents of the first and second questionnaires were analyzed on 43 programs and 33 programs, respectively. Results: The questionnaire responses revealed that there were relatively larger number of curriculum subjects in associate's degree programs than bachelor's degree programs because the associate's degree programs tended offer other certification courses in conjunction with the SLP program. It was also found that some SLP programs limited number of students in a class to offer better student support and offered different sets of electives and mandatory courses. In the analysis of the curriculum improvement proposals, it was found that the most common keywords included 'school age', 'elderly/aging','augmentative and alternative communication', and 'IT (information technology).' Conclusion: In this study, we provide the picture of the current SLP programs in Korea. The results of this study could be used as the basis for the SLP programs' continued improvement in the future.

Keywords: Education programs, Curriculum, Speech-language pathology (SLP), Speech therapy, Questionnaire
우리나라의 언어재활사 양성 과정 프로그램은 1988년에 대구대 학교에 학사과정이 개설된 것을 기점으로 2018 년 현재, 총 87 개 과 정이 운영되고 있다. 이를 통하여 지난 30 여 년 동안 수많은 언어재
활사가 배출되었으며, 최근에는 연간 1천여 명 이상의 졸업생을 배 출하는 비약적 팽창을 이루었다. 그러나 점차 감소하는 학령 인구 로 인하여 대두된 정원 충원 문제와 언어재활사라는 직업에 대한 
인지도 부족과 같은 작금의 문제들에 대해 함께 고민하고 해결방 법을 모색하여 새로운 30 년을 준비해야 할 시점이라고 볼 수 있다.

언어재활사양성 과정의 역사를 좀더 구체적으로 살펴보면, 1988 년 대구대학교에 최초의 언어치료 학사과정이 설립된 이후, 1995년 이화여자대학교에 언어병리학협동과정으로 최초의 석사과정이, 1999년 춘해보건대학교에 최초의 전문학사과정이 개설되었다. 2018년 3월 현재, 전국언어치료학과협의회(이하 전언협)에 등록된 언어재활전공 프로그램이 개설되어 있는 학교는 총 50 개교로서 4 년제 대학교(이하 대학교) 24 개교, 전문대학(이하 전문대) 12 개교, 대학원 14 개교(이하 대학원)이며, 이들 50 개 학교에서 총 87 개(1개 의 대학에서 복수의 교육과정이 존재함) 교육과정 프로그램이 운 영되고 있다. 이들 87 개의 교육과정에서 매년 천여 명을 상회하는 졸업생을 배출하고 있고, 언어재활사 국가자격시험에 응시할 수 있 는 인력을 양성하고 있는 것이다(Kim et al., 2013). 언어재활사 양 성 교육과정은 대학교, 전문대, 대학원의 다양한 학제에서, 각각 학 사(bachelor's degree), 전문학사(associate's degree), 석사 및 박사 (master's \& doctoral degrees) 학위를 수여하고 있다. 약 30년에 걸 친 교육 학제의 변천 과정에서 신설되거나 학제를 변경하는 경우도 많았고, 폐교가 된 경우도 있었으며, 교명이 바뀌기도 하면서, 언어 재활사 양성 교육과정은 우리나라 교육사 및 보건복지사의 변천과 맞물려 다사다난하게 변천되어 왔다.

Figure 1은 각 학제에 따른 언어재활 양성 교육과정 수에 따른 분 포(2018년 3월 현재 기준)를 나타내며, 절반 이상의 교육과정이 석 사 및 박사학위 교육과정인 것을 알수 있다.

언어재활사 자격은 2012년부터 보건복지부에서 인정하는 언어 재활사 양성 교육과정을 졸업하고, 한국보건의료인국가시험원(이 하 국시원)이 주관하는 1 급 언어재활사 혹은 2 급 언어재활사 국가 시험 합격 후 보건복지부에서 발행하는 자격증을 취득해야 하는

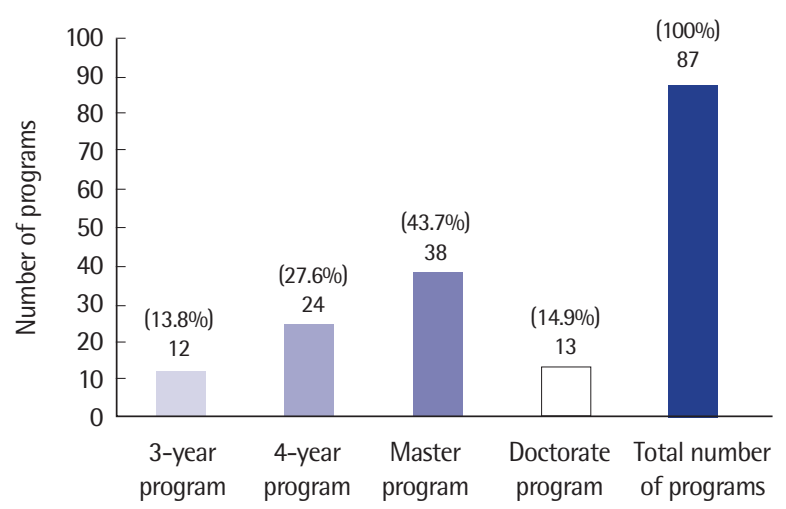

Figure 1. Current number of academic programs of speech-language pathology in Korea (as of March, 2018).
국가자격제도로 전환되었다. 또한 높은 전문성을 요구하는 직업이 므로 자격증 취득 후에도 사단법인 한국언어재활사협회에서 주관 하는 보수교육을 연간 8시간 이수해야 자격이 유지되는 구조로 운 영되고 있다. 한국언어재활사협회는 매년 초에 다양한 보수교육 프 로그램을 소개하고 있으며, 언어재활사의 접근성을 고려하여 지부 별 보수교육을 개최하는 등 재교육을 위한 다양한 노력을 하고 있 다. 그러나 무엇보다도 대학과 대학원에서 예비 언어재활사들의 자 질을 향상시키고, 언어병리학적 소양을 충분히 쌓도록 함으로써 준 비된 언어재활사를 배출하는 것이 가장 우선시 되어야 할 부분이 다. 사회와 임상현장이 요구하는 우수한 언어재활사를 양성하기 위하여 언어병리학이 개설되어 있는 대학의 부단한 노력이 요구된 다. 이에 현재 언어재활사 양성 과정을 분석하고 교육과정을 효과 적으로 운영, 관리할 수 있는 방안을 모색하기 위한 언어재활전공 교과과정 운영 실태 조사에 대한 필요성이 제기되었다.

국시원에서는 언어재활사 국가시험 응시자격으로 장애인복지법 시행규칙 제 57 조의 4 , 별표 6 의 2 에 의거하여 언어재활 관련 교과 목 이수를 명시하고 있다. 11 개의 필수과목이 있으며, 23 개 선택과 목 중 9과목을 이수하여 총 20 개 교과목을 이수하도록 명시하고 있으므로 언어병리학이 개설된 대학에서는 이러한 기준에 부합하 도록 교과과정을 구성하고 있다. 그러나 학령인구 감소로 인하여 대학은 구조적 변화를 겪고 있으며 이에 따라 졸업학점의 재조정 등이 요구되면서 언어재활사 양성 과정도 교과목 편성에 다소의 어 려움을 겪기 시작하고 있다. 실무역량 강화가 요구되는 언어재활 분야에서는 졸업 후 바로 실무를 수행할 수 있도록 체계적인 교과 과정을 운영해야 하므로 현 시점에서 각 양성 과정에서 겪고 있는 어려움을 파악하고 미래의 방향성을 모색해보는 것이 필요하다는 판단 하에 본 연구가 시작되었다.

이러한 연구의 필요성을 바탕으로 본 연구에서는 전국에 언어재 활전공이 개설된 대학의 기본정보를 분석하여 현황을 살펴보고, 각 대학의 전공 교과과정의 현황을 학제별(대학교, 전문대, 대학원) 로 나누어 정리 및 분석하여 국내 언어재활전공 교과과정의 현재 모습을 살펴보고자 하였다. 또한 언어재활전공이 개설된 전국 대학 의 교과과정 수요를 파악하여 향후 언어재활전공 교과과정 개선을 위한 제언 및 우수한 언어재활사 양성을 위한 미래의 방향 모색을 하고자 하였다.

\section{연구방법}

\section{설문지 작성}

국내 언어재활전공의 교과과정 현황을 조사하기 위하여 언어재 
활 및 관련 전공의 교육과정 현황 및 인증제에 관한 선행연구(Kim et al., 2013; Lee et al., 2017; Yun et al., 2010)를 참고하여 설문지를 작성하였다. 설문지의 내용타당도는 국내 언어치료를 대표하는 양 학회인 한국언어치료학회와 한국언어청각임상학회의 2-3명의 자 문위원단과 연구진들과의 수차례 회의를 통하여 예비문항의 내용 타당도를 검증하였고, 검토된 내용을 바탕으로 일부 문항 수정 과 정을 거쳐 최종 설문 문항을 제작하였다.

설문지는 1 차 및 2 차 설문지로 나누어 제작 및 배포하였다. 1 차 설문지는 크게 두 가지 영역으로 구성하였는데, 첫 번째는 대학의 기본정보에 관한 것이고, 두 번째는 전공 교과과정에 대한 정보를 포함하였다. 대학 기본정보에는 학과명, 주소, 개설연도, 재직 전임 교수 수, 정원, 졸업연한과 요건, 타 전공 학생의 복수전공/부전공 허용 여부 등을 포함하였다. 전공 교과과정에는 교과목명, 각 교과 목에 대한 상세정보(개설학년, 개설학기, 학점, 시수, 전공선택 및 전공필수, 이론 및 실습, 분반 여부, 각 교과목 담당교수의 전임 여 부)를 포함하였다. 전공 교과과정은 연간 교과과정 변화를 반영하 기 위해 최근 3년간(2015년 1학기 및 2학기, 2016년 1학기 및 2학기, 2017년 1학기 및 2학기) 개설한 교과과정으로 작성할 것을 요청하 였다. 2017년 11월 4일에 개최된 전언협 정기총회에서 1차 설문지 분석 결과를 발표하고 각 학교의 대표교수들과 논의 및 의견수렴 과정을 거쳐 전공 교육과정에 대한 2 차 설문지를 추가적으로 제작 하였다. 2 차 설문지는, 현재 대학 실정에 따른 전공 교과목 미개설 현황 및 신설 개설 희망 교과목 등 교과목 수요와 관련된 질문을 포함하였다(Appendix 1). 즉 1차 설문지 내용은 현재 전공 교과과 정에 대한 현황을 파악하기 위한 설문이며 2차 설문지는 언어재활 사 양성을 위하여 미래의 방향성을 모색하기 위해 제작된 설문으 로, 내용이 분리되어 있으므로 1 차 설문 답변 여부와 상관없이 모 든 대학에 다시 설문을 배포 및 회수하였다.

\section{조사대상 선정 자료수집}

국내 언어재활전공의 교과과정을 분석하기 위하여 전언협 회원 교를 대상으로 설문조사를 실시하였다. 대상이 되는 학과 범위는 대학교 및 전문대의 경우, 언어치료, 언어재활, 언어청각치료가 학 과명에 표기된 학과로서 언어재활사 양성을 위한 교육과정이 마련 된 대학이다. 2018년부터 교육과정 운영이 시작되는 학교는 포함하 지 않았다. 대학원의 경우, 언어치료, 언어재활, 언어병리학이 전공 으로 표기된 학교를 조사 대상으로 포함하였다. 대학교 및 대학원 과정 혹은 일반대학원과 특수대학원이 함께 개설된 학교의 경우, 개설된 각 과정에 대하여 각각 개별적으로 설문을 회수하였다.

본 조사연구의 자료는 엑셀로 작성하여 이메일을 통해 배포하고
Table 1. Number of academic programs in speech language pathology in Korea included in the survey

\begin{tabular}{|c|c|c|c|}
\hline Region & $\begin{array}{l}\text { Number of } \\
\text { schools for data } \\
\text { collection }\end{array}$ & $\begin{array}{c}\text { Analysis target } \\
\text { for primary } \\
\text { questionnaire }\end{array}$ & $\begin{array}{l}\text { Analysis target for } \\
\text { secondary ques- } \\
\text { tionnaire }\end{array}$ \\
\hline Bachelor's degree ${ }^{a}$ & 19 & 16 & 11 \\
\hline Seoul/Gyeonggi-do & 1 & 1 & 0 \\
\hline Gyeongsang-do & 5 & 5 & 4 \\
\hline Jeolla-do/Jeju & 9 & 6 & 4 \\
\hline Chungcheong-do & 3 & 3 & 2 \\
\hline Gangwon-do & 1 & 1 & 1 \\
\hline Associate's degree & 13 & 8 & 4 \\
\hline Seoul/Gyeonggi-do & 1 & 1 & 0 \\
\hline Gyeongsang-do & 5 & 3 & 1 \\
\hline Jeolla-do/Jeju & 3 & 1 & 1 \\
\hline Chungcheong-do & 2 & 2 & 2 \\
\hline Gangwon-do & 1 & 1 & 0 \\
\hline Master's degree & 31 & 19 & 18 \\
\hline Seoul/Gyeonggi-do & 10 & 8 & 4 \\
\hline Gyeongsang-do & 6 & 2 & 3 \\
\hline Jeolla-do/Jeju & 10 & 4 & 6 \\
\hline Chungcheong-do & 3 & 3 & 3 \\
\hline Gangwon-do & 2 & 2 & 2 \\
\hline Total & 63 & 43 & 33 \\
\hline
\end{tabular}

a3-year programs.

수집하였다. 언어재활전공이 개설된 대학의 대표교수를 대상으로 안내문과 설문지를 배포하고, 자료를 수집하였다. 수집된 자료를 보완하기 위해 필요한 경우 대표교수와 직접 전화연락을 통해 설 문 내용의 확인 및 보완을 요청하였다. 2018년 3월 27일까지 회수된 자료를 바탕으로 분석을 실시하였으며, 잘못 기재된 정보를 확인할 수 없거나 기입이 되어 있지 않은 학교는 제외하고 분석하였다. 1 차 설문지에서 기본정보 분석의 대상 학교는 총 48 개로, 대학교 17 개, 전문대 9 개, 대학원 22 개교였다. 1 차 설문지에서 자료의 누락, 확인 등을 고려하여 교육과정 분석의 대상 학교는 총 43 개교로, 대학교 16 개교, 전문대 8 개교, 대학원 19 개교이었다. 2 차 설문지의 분석 대 상으로 선정된 대학은 총 33 개교로, 대학교 11 개교, 전문대 4 개교, 대학원 18 개교이었다. 최초 자료수집 대상 및 최종 분석 대상 학교 는 Table 1과 같다.

\section{분석방법}

분석은 기본정보 및 교과과정 분석(1차 설문지)과 기타 설문 분 석(2차 설문지)으로 이루어졌다. 기본정보에는 학제(대학교, 전문대, 대학원), 지역, 개설연도, 편제정원, 재직 전임교수 수, 졸업연한과 요건, 타 전공 학생의 복수전공/부전공 허용 여부 등을 포함하였다. 
교과과정 분석을 위한 문항으로는 학제별 전체 전공교과목 수, 학년별 전공교과목 수, 학점 및 시수별 교과목 수, 이수별(전공필수 및 전공선택) 교과목 수, 이론/실습/이론 및 실습 중심 교과목 수, 각 교과목 교수진의 전임 및 비전임 여부를 포함하였다. 설문 결과 를 통하여 전체 교과목 수에 대한 각 항목의 평균과 최소 및 최대값 을 파악하였다. 또한 학제별 전체 전공교과목 수에 따른 각 항목의 비율과 언어재활사 외 자격증과정 여부를 살펴보았다. 분석 시 교 양 교과목은 포함시키지 않았으며, 각 교과목의 담당교수에 대한 전임/비전임 여부에는 기입이 되어 있지 않고 ‘타 전공 교수”로만 작 성된 경우 '비전임'으로 간주하여 분석하였다. 대학원의 경우, 같은 학교에 일반 및 특수대학원 과정이 따로 있을 경우 각 과정에 대해 각각 입력 및 분석하였다.

다음으로, 언어재활전공 교과과정에 대한 수요 분석을 위하여 전공 이수 학점을 줄여야 할 경우 어떠한 선택을 할 것인지, 2017년 1,2 학기에 개설하고자 하였으나 여건상 개설하지 못한 교과목이 있는지, 미래 언어재활사 양성에 필요한 전공교과목과 그 사유에 대한 설문 결과를 분석하였다(Appendix 1).

\section{연구결과}

\section{언어재활전공 개설 현황}

설문지의 기본사항에 기록된 정보를 바탕으로 언어재활전공이
개설된 학제별 분석을 실시하였다. 대학교에 개설되어 있는 언어재 활전공 현황은 Table 2 와 같다.

학사과정으로 개설된 대학교 중 기본사항에 응답한 17 개교의 내용을 분석한 결과, 1988년부터 2013년에 이르기까지 언어재활전 공이 개설되었으며 졸업학점은 최소 120 학점에서 157 학점까지로 나타났다. 전임교수 수는 1 명부터 많게는 11 명까지이고, 평균 4.29 명으로 나타났다. 대부분의 대학교에서는 복수전공 및 부전공을 허용하고 있으며 졸업고사를 통과하는 것을 졸업요건으로 명시하 고 있었다. 편제정원 수는 최소 27 명부터 최대 60 명까지인 것으로 조사되었다.

전문대에 개설되어 있는 언어재활전공 현황은 Table 3 과 같다.

기본정보 설문에 응답한 전문대 9개교는 1999년부터 2012년까 지 개설된 대학들이며, 대부분이 3년제로 운영되고 있지만 3학년 졸업 후 1 년 전공심화과정을 이수하게 하여 4 년제와 동일한 학사 학위증을 발급하는 전문대가 3 개교 있었다. 졸업요건으로는 최소 112 학점부터 140 학점까지 이수하도록 운영하고 있었다. 전임교수 수는 1 명에서 최대 6 명까지이며 평균 2.78 명으로 나타났다.

대학원에 개설되어 있는 언어재활전공 현황은 Table 4 와 같다.

대학원에 개설되어 있는 24 개 프로그램의 기본사항 응답 내용 을 분석한 결과, 1992년부터 2015년에 이르기까지 일반대학원, 특 수대학원, 교육대학원 등에서 언어재활전공을 개설하고 있는 것으 로 나타났다. 한 대학 내에 일반대학원과 특수대학원을 함께 운영

Table 2. Speech-language pathology program curriculum for bachelor's degree in Korea

\begin{tabular}{|c|c|c|c|c|c|c|c|}
\hline Region & University & $\begin{array}{c}\text { Established } \\
\text { year }\end{array}$ & Quota & $\begin{array}{l}\text { Number of } \\
\text { faculty }\end{array}$ & $\begin{array}{c}\text { Required } \\
\text { credits }\end{array}$ & Graduation requirements & Permission of dual major \\
\hline Seoul/Gyeonggi-do & $\mathrm{H}$ & 2007 & 30 & 4 & 130 & - & 0 \\
\hline \multirow[t]{5}{*}{ Gyeongsang-do } & $E$ & 2010 & 40 & 4 & 140 & Social service, portfolio & 0 \\
\hline & $\mathrm{F}$ & 1988 & 36 & 5 & 130 & Examination & 0 \\
\hline & G & 2010 & 40 & 4 & 135 & Examination & 0 \\
\hline & 1 & 2006 & 57 & 6 & 135 & - & $X$ \\
\hline & C & 2010 & 30 & 4 & 140 & Thesis, examination, TOEIC & 0 \\
\hline \multirow[t]{7}{*}{ Jeolla-do/ Jeju } & $\mathrm{B}$ & 2006 & 30 & 5 & 120 & Examination & 0 \\
\hline & A & 2007 & 30 & 3 & 130 & - & 0 \\
\hline & $J$ & 1999 & 30 & 4 & 130 & Examination & 0 \\
\hline & 0 & 2013 & 30 & 3 & 130 & - & $x$ \\
\hline & $\mathrm{M}$ & 2012 & 40 & 2 & 130 & Examination & 0 \\
\hline & $\mathrm{N}$ & 2007 & 27 & 5 & 130 & - & 0 \\
\hline & $P$ & 2012 & 28 & 5 & 130 & Examination & 0 \\
\hline \multirow[t]{3}{*}{ Chungcheong-do } & $D$ & 2000 & 60 & 7 & 127 & Examination & 0 \\
\hline & K & 2005 & 50 & 1 & 156 & Examination & 0 \\
\hline & $\mathrm{L}$ & 2011 & 30 & 3 & 120 & Examination & 0 \\
\hline Gangwon-do & 0 & 2001 & - & 11 & 130 & KSLP certification, examination & 0 \\
\hline
\end{tabular}

$\mathrm{KSLP}=$ Korean Association of Speech-Language Pathologists. 
Hyun Rin Park, et al. • Curriculum in Speech-Language Pathology Programs

Table 3. Speech-language pathology program curriculum for associate's degree in Korea

\begin{tabular}{|c|c|c|c|c|c|c|c|}
\hline Region & College & $\begin{array}{c}\text { Established } \\
\text { year }\end{array}$ & Quota & $\begin{array}{l}\text { Number of } \\
\text { faculty }\end{array}$ & $\begin{array}{c}\text { Required } \\
\text { credits }\end{array}$ & Graduation requirements & $\begin{array}{l}\text { Duration for } \\
\text { graduation (yr) }\end{array}$ \\
\hline Seoul/Gyeonggi-do & C & 2011 & 40 & 3 & 120 & - & 3 \\
\hline \multirow[t]{3}{*}{ Gyeongsang-do } & A & 2012 & 30 & 1 & 112 & - & 3 \\
\hline & B & 2004 & $70+25^{a}$ & 6 & 120 & - & $3+1$ \\
\hline & G & 1999 & 110 & 4 & 120 & Certification of practical abilities & $3+1$ \\
\hline \multirow[t]{2}{*}{ Jeolla-do/Jeju } & $\mathrm{E}$ & 2004 & 25 & 2 & 120 & - & 3 \\
\hline & । & 2008 & 20 & 1 & 120 & - & 3 \\
\hline \multirow[t]{2}{*}{ Chungcheong-do } & $\mathrm{F}$ & 2012 & 40 & 2 & - & - & 3 \\
\hline & $\mathrm{H}$ & 2004 & $40+20^{b}$ & 3 & $120+20^{b}$ & - & $3+1$ \\
\hline Gangwon-do & $D$ & 2012 & 46 & 3 & 135 & - & 3 \\
\hline
\end{tabular}

${ }^{a}$ Quota for the intensive major course. ${ }^{b}$ Credits required for the intensive major course.

Table 4. Speech-language pathology program curriculum for master's and doctoral degree in Korea

\begin{tabular}{|c|c|c|c|c|c|c|}
\hline Region & University & Established year & Number of faculty & Required credits ${ }^{\mathrm{a}}$ & Graduation requirements & Degree \\
\hline \multirow[t]{9}{*}{ Seoul/Gyeonggi-do } & $A$ & 2012 & 1 & 30 & Thesis or examination & Master's (special) \\
\hline & B & 2002 & 1 & 30 & Examination & Master's (education) \\
\hline & G & 1997 & 3 & 30 & Thesis & Master's (special) \\
\hline & $\mathrm{H}$ & 2012 & 3 & $33 / 45$ & Thesis & Master's, Doctoral \\
\hline & $\mathrm{T}$ & 2008 & 4 & 30 & Thesis & Master's \\
\hline & K & 2002 & 2 & $36 / 36$ & $\begin{array}{c}\text { Thesis, examination } \\
\text { Thesis }\end{array}$ & $\begin{array}{l}\text { Master's (special) } \\
\text { Doctoral }\end{array}$ \\
\hline & $\mathrm{L}$ & 1998/2000 & 1 & $30 / 30$ & Examination+thesis & Master's, Doctoral \\
\hline & M & 2002 & 1 & $\begin{array}{l}43 \text { (non-majors) } \\
24 \text { (majors) }\end{array}$ & Thesis, examination & Master's (special) \\
\hline & $\mathrm{N}$ & 1995 & 4 & $24 / 60$ & $\begin{array}{c}\text { Thesis, examination } \\
\text { Thesis }\end{array}$ & $\begin{array}{c}\text { Master's (education) } \\
\text { Doctoral }\end{array}$ \\
\hline \multirow[t]{5}{*}{ Gyeongsang-do } & U & 2014 & 4 & $24 / 36$ & Examination+thesis & Master's, Doctoral \\
\hline & V & 2012 & 4 & $\begin{array}{c}24 \text { (thesis) } \\
30 \text { (examination) }\end{array}$ & Thesis, examination & Master's (special) \\
\hline & । & 1997 & 5 & $24 / 36$ & Examination+thesis & Master's, Doctoral \\
\hline & J & 1992 & 5 & 24 & Examination & Master's (special) \\
\hline & W & 2009 & 6 & 24 & Examination, thesis & Master's \\
\hline \multirow[t]{6}{*}{ Jeolla-do/Jeju } & D & 2014 & 3 & 24 & Alternative subject, thesis & Mater's (special) \\
\hline & $E$ & 2006 & 3 & 27 & Examination, thesis & Master's (special) \\
\hline & $x$ & 2000 & 1 & $24 / 36$ & Thesis & Master's, Doctoral \\
\hline & 0 & 2007 & 5 & $24 / 36$ & Thesis & Master's, Doctoral \\
\hline & S & 2013/2015 & 5 & $24 / 36$ & Thesis & Master's, Doctoral \\
\hline & Y & 2015 & 2 & 30 & Special report, thesis & Master's (special) \\
\hline \multirow[t]{3}{*}{ Chungcheong-do } & C & 2014 & 0 & $\begin{array}{c}49 \text { (examination) } \\
43 \text { (thesis) }\end{array}$ & Thesis, examination & Master's (special education \\
\hline & $\mathrm{F}$ & 2000/2009 & 7 & $28 / 36$ & Thesis & Master's, Doctoral \\
\hline & $P$ & 2005 & 0 & $24 / 36$ & Thesis & Master's, Doctoral \\
\hline \multirow[t]{2}{*}{ Gangwon-do } & 0 & 1998 & 6 & $\begin{array}{c}24 \text { (thesis) } \\
32 \text { (examination) }\end{array}$ & Thesis or examination & Master's (special) \\
\hline & $\mathrm{R}$ & & & $28 / 40$ & Thesis & Master's, Doctoral \\
\hline
\end{tabular}

aCredits required for master's degree/doctoral degree. 
하는 대학이 4 개교 있으며, 12 개 대학에서 박사과정을 운영하고 있 었다. 졸업요건으로는 시험(qualifying examination)과 논문(thesis) 중 선택하거나 논문과 시험을 모두 통과해야 되는 대학도 있었 다. 졸업 이수학점은 대학 전공자/비전공자 혹은 논문/시험 선택 요 건에 따라 다소 차이가 있었으나, 최소 24학점에서 최대 60학점까 지인 것으로 나타났다. 전임교수가 없이 운영되고 있는 대학원부터 최대 7명의 전임교수로 운영되고 있는 대학원도 있었으며 평균 3.17 명의 전임교수가 재직 중인 것으로 나타났다.

\section{언어재활전공 교육과정 현황}

설문에 응답한 모든 대학의 언어재활전공에서 개설된 교과목의 평균 수와 범위를 Figure 2에 나타냈으며, 이에 대한 각 학교별 개설 교과목과 학년별 분포 상세 내용을 Appendices 2, 3에 제시하였다.

대학교의 경우, 연간 평균 33.8 개 교과목이 개설되었으며 분석에 포함된 16 개교 중 개설된 전공 교과목 수가 가장 많은 대학교의 교 과목 수는 43 개, 가장 적은 대학교의 교과목 수는 28 개로 나타났 다. 전문대의 경우, 연간 평균 42.6 개의 교과목이 개설되었으며 분 석에 포함된 전문대 8 개교 중 개설된 전공 교과목 수가 가장 많은 학교의 교과목 수는 52 개, 가장 적은 학교의 교과목 수는 35 개로 나타났다. 대학원은 연간 평균 19.3 개의 교과목이 개설되었으며 총 19 개의 학교 중 개설된 전공 교과목 수가 가장 많은 학교의 교과목 수는 37 개, 가장 적은 학교의 교과목 수는 6개로 나타났다. 이로써 개설된 평균 교과목 수는 전문대가 가장 많은 것을 알 수 있다.

연간 개설되는 교과목 수에 대한 학제별 차이를 좀 더 상세히 살 펴보기 위해 개설된 전공 교과과정 중 언어재활사 외 자격증 교육 과정이 전공 교과목으로 개설된 현황을 분석하여 Table 5 에 제시 하였다.

대학교의 경우 16 개교 중 5 개교에서 언어재활사 자격증 외 타 자

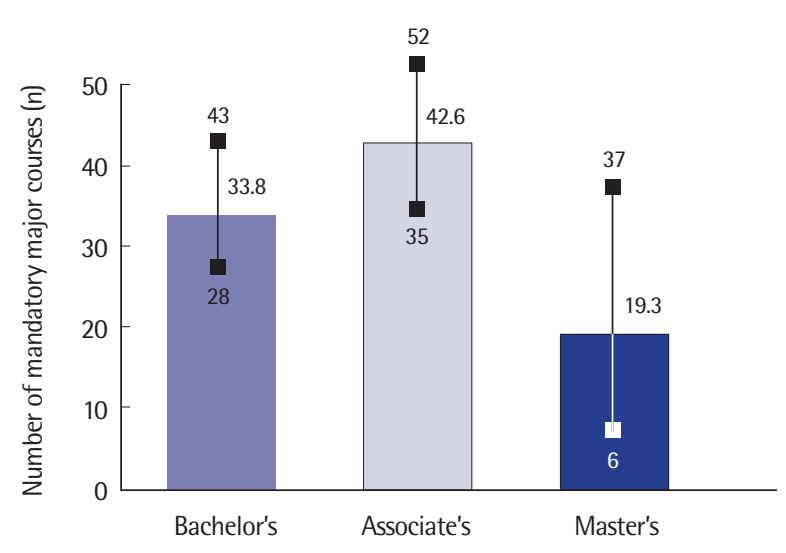

Figure 2. Number of mandatory major courses within the curriculum per year.
격증 교육과정을 전공과목으로 개설하고 있었다(청각사 4 개교, 미 술치료사 1 개교). 여기에는 대학교 중 개설 교과목 수가 가장 많은 3 개 대학교(각각 40 개, 38 개, 43 개)가 포함되어 있으며, 청각사 등을 위한 이론 및 실습 교육과정을 개설하고 있어 교과목 수가 타 대학 교에 비해 비교적 많은 것을 확인할 수 있었다. 전문대는 8 개교 모 두 언어재활사 양성 과정에 추가적으로 타 자격증 취득을 위한 교 과목을 개설하고 있었다(보육교사 6개교, 장애영유아보육교사 2개 교, 연극치료사, 사회복지사, 심리치료사, 미술재활사 각 1 개교). 또 한 전문대 8 개교 중 4 개교에서는 2 개 이상의 타 자격증 과정이 개설 되어 있었으며 이러한 점이 연간 교과목 수에 영향을 미친 것을 알 수 있었다. 대학원에서 언어재활사 외 타 자격증 교육과정이 개설 된 경우는 2 개교가 있었으며, 모두 청각사 과정이 개설되어 있었다. 한편 언어재활사 외 타 자격증 교육과정으로 전문대에서는 대부분 보육교사 과정을 개설하고 있으나, 대학교와 대학원에서는 청각사 과정을 개설하고 있는 것으로 나타났다.

Figure 3에는 전체 교과목 중 전공필수 및 전공선택 교과목이 차 지하는 비율을 나타내었다. 대학원의 경우, 전공선택과 필수 구분 을 두지 않는 학교가 많아 이에 대한 분석을 따로 실시하지 않았다. 대학교의 경우 전공필수 과목이 $19.5 \%$ 로 적게는 0 개에서 많게는

Table 5. Number of schools offering major mandatory courses for the additional certificate

\begin{tabular}{lcc}
\hline Degree & Survey target schools & $\begin{array}{c}\text { Schools offering the additional } \\
\text { certificate }\end{array}$ \\
\hline Bachelor's & 16 & $5(31.2)$ \\
Associate's & 8 & $8(100)$ \\
Master's & 19 & $2(10.5)$ \\
Total & 43 & 15 \\
\hline
\end{tabular}

Values are presented as number (\%).

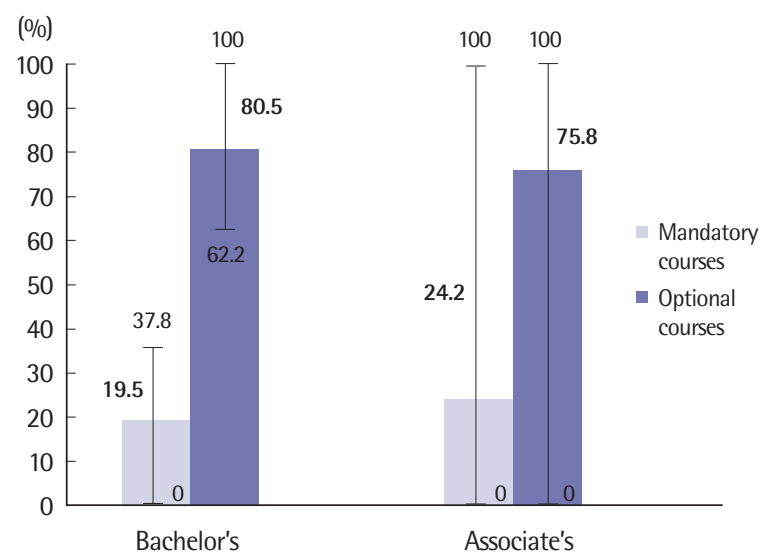

Figure 3. Distribution of mandatory and optional courses. 
14 개까지(0\%-37.8\%) 분포되어 있었으며, 전공선택 과목이 $80.5 \%$ 로 적게는 21 개에서 많게는 43 개까지(62.2\%-100\%) 포함되어 있었다. 분석에 포함된 모든 대학교에서 전공선택 과목이 전공필수 과목과 비교하여 많은 것을 확인할 수 있었으며 모든 교과목을 전공선택 과목으로 지정한 대학도 있음을 확인할 수 있었다. 전문대의 경우 전공필수 과목이 $24.2 \%$, 전공선택 과목이 $75.8 \%$ 로 대학교와 비슷 한 양상을 보였으나, 학교마다 전공필수 및 전공선택 교과목의 편 차가 매우 큰 것을 알 수 있었다. Appendix 4을 살펴보면 전문대 $\mathrm{G}$ 대학 및 $\mathrm{H}$ 대학 외의 모든 전문대에서 전공필수 과목이 0-8개(0\%$19.1 \%)$, 전공선택 과목이 21-39개(80.9\%-100\%)까지 포함되어 있어 전공선택의 비율이 높았으나, $\mathrm{G}$ 대학과 $\mathrm{H}$ 대학의 경우 전공필수 과 목의 비율이 각각 $55.3 \%, 100 \%$ 로 학교에 따라 상당히 많은 교과목 을 전공필수 과목으로 지정한 전문대도 있음을 알 수 있었다.

Figure 4에는 전체 개설 교과목 중 이론, 실습, 이론 및 실습 교과 목이 차지하는 비율을 제시하였다. 언어재활사 국가시험 응시를 위 하여 언어재활현장실무, 언어재활관찰, 언어진단실습, 언어재활실 습과 같은 실습 교과목을 필수적으로 이수해야 하는 등 실습 교과 목이 매우 중요하다. 이에 각 학제별 실습 교과목 현황을 살펴보기 위해 이론, 실습, 이론 및 실습 교과목으로 분류하여 현황을 살펴보 았다(Appendix 4). 대학교의 경우, 이론 교과목, 실습 교과목, 이론 및 실습 교과목의 비율은 각각 $73.8 \%$ (37.1\%-87.5\%), $13.1 \%$ (0\%$20.9 \%), 13.1 \%$ (0\%-51.4\%)이며, 전문대의 경우는 각각 $40.8 \%(0 \%-$ $58.1 \%), 16.6 \%$ (0\%-41.9\%), $42.6 \%$ (0\%-92.1\%), 대학원의 경우 각각 $82.9 \%$ (63.6\%-100\%), 14.8\% (0\%-36.4\%), 2.3\% (0\%-9.5\%)였다. 즉 대학교 및 전문대의 경우 실습 교과목이 전혀 개설되지 않은 것으 로 분석된 학교도 있어 상세한 교과목 현황을 살펴본 결과, 언어재 활현장실무, 언어재활관찰, 언어진단실습, 언어재활실습에 해당하

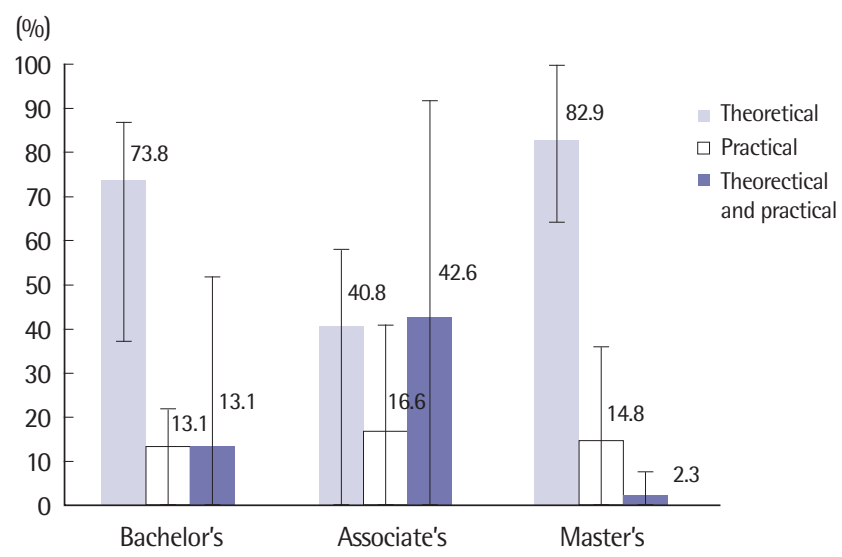

Figure 4. Distribution of courses for theoretical education, practical education, and education/practical education.
는 교과목이 개설되지 않은 것이 아니라 이를 이론 및 실습 교과목 으로 분류하여 개설하고 있기 때문이라는 것을 알 수 있었다. 또한 대학원 중에도 실습 교과목을 개설하지 않고 이론 교과목만 개설 한 학교가 다수 있는 것으로 나타났다.

교과과정 운영을 보다 상세하게 살펴보기 위하여 2개 이상 분반 으로 운영하고 있는 교과목 현황과 명칭을 살펴보고 그 내용을 Appendix 5 에 제시하였다. 대학교의 경우 총 16 개교 중 13 개교, 전문 대의 경우 총 8 개교 중 6 개교, 대학원의 경우 총 19 개교 중 8 개교에 서 분반 형태의 수업을 운영하고 있었다. 대부분의 전문대 및 대학 교에서 분반으로 운영하고 있는 교과목을 살펴보면 언어재활관찰, 언어진단실습, 언어재활실습 교과목이 대부분인 것을 알 수 있었 다. 이러한 교과목들은 학교에 따라, 적게는 1 개 분반에서 많게는 5 개 분반으로 운영하고 있었다. 특히 Appendix 5에 제시한 학교 중 대학원 $\mathrm{Q}$ 와 $\mathrm{R}$ 을 제외한 모든 학교에서 '언어재활실습’ 과목을 분 반으로 운영하고 있었다. 언어재활사 국가시험 응시를 위하여 45시 간 이상의 교내 실습이 필수적이므로 모든 학교에서 교내 치료실을 운영하며 학생들의 실습 지도와 수업을 진행하고 있다. 이를 통해 많은 대학에서 원활하고 질 높은 실습 지도를 위해 소규모 강좌를 개설하여 운영하고자 함을 확인할 수 있었다. 또한 학교정책이나 교육이념에 따라 전공 교과목들이 분반 형태로 운영되고 있음을 알 수 있었다.

각 학제에 따른 전공 교과목의 학점 분포 현황을 Figure 5에 비 율로 제시하였다(학교별 상세 학점 분포는 Appendix 6 참조). 전공 교과목의 학점 분포 현황은 대학교의 경우 1 학점 교과목이 $2.1 \%$ (최소 0 개에서 최대 2개), 2 학점 교과목이 $18.6 \%$ (최소 0 개에서 최 대 23개), 3 학점 교과목이 $77.1 \%$ (최소 15 개에서 최대 34 개)였다. 전 문대의 경우 1 학점 교과목이 차지하는 비율이 $0.9 \%$ (최소 0 에서 최 대 1 개 교과목), 2 학점 교과목은 $17.6 \%$ (최소 0 에서 최대 15 개), 3 학 점 교과목은 $81.4 \%$ (최소 19 개에서 최대 47 개)이었다. 대학원의 경

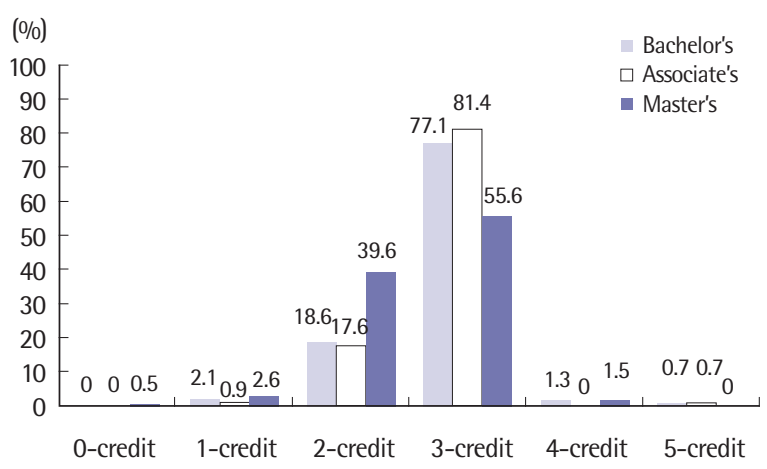

Figure 5. Distribution of courses credit. 


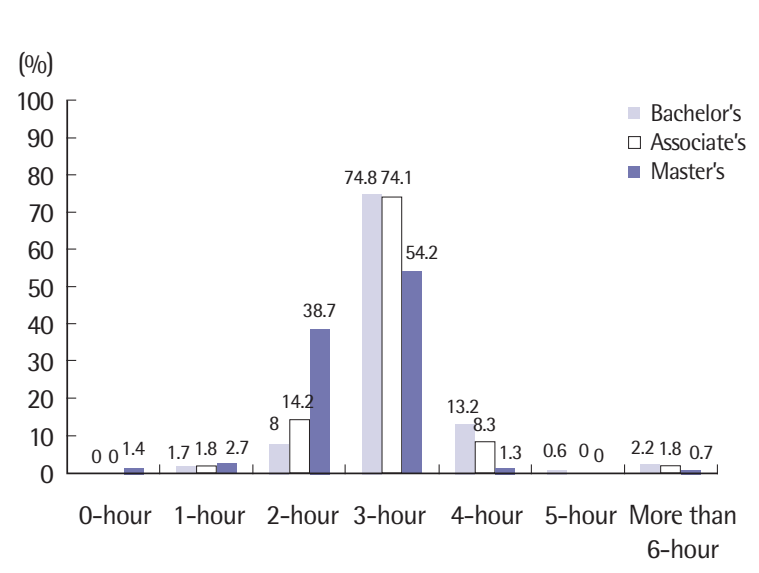

Figure 6. Distribution of instruction time per course.

우 2학점 교과목이 $39.6 \%$ (최소 0에서 최대 37개), 3학점 교과목이 $55.6 \%$ (최소 0에서 최대 29개)였다. 대학교와 전문대의 경우 학교 간 어느 정도 차이는 있으나 학점별 교과목의 비율은 비슷하였으 며, 학부 J대학을 제외한 모든 학교에서 3학점 교과목이 2학점 교 과목보다 많은 것을 알 수 있었다. 한편 K대학교에서는 4학점 및 5 학점 교과목을 각각 6 개, 4 개씩 운영하고 있었다. 대학원의 경우 학 교마다 차이는 있으나 2 학점 교과목의 비율이 전문대 및 대학교에 비해 높은 것을 알수 있었다.

각 학제에 따른 전공 교과목의 시수 분포 현황을 Figure 6에 비율 로 제시하였다(학교별 상세 학점 분포는 Appendices 7, 8 참조). 대 학교의 경우 2 시수 교과목이 $8.0 \%$ (최소 0에서 최대 9개), 3 시수 교 과목이 $74.8 \%$ (최소 15 에서 최대 36 개), 4 시수 교과목이 $13.2 \%$ (최 소 0 에서 최대 14 개)였다. 전문대의 경우 2 시수 교과목이 $14.2 \%$ (최 소 0 에서 최대 15 개), 3 시수 교과목이 $74.1 \%$ (최소 19개에서 최대 40 개), 4 시수 교과목이 $8.3 \%$ (최소 0 에서 최대 11 개)였다. 학제 간 세 부적인 비율에서 차이를 보이기는 하나 대학교와 전문대 모두 3 시 수가 가장 많은 것이 공통점이었으며 대부분의 교과목이 2에서 4 시수 사이에 포함되어 있다는 공통점이 있었다. 단 대학교는 전문 대에 비하여 4 시수 교과목이 다수 많고 2 시수 교과목이 다수 적은 것을 알 수 있다. 대학원의 경우 전체적인 평균은 2 시수가 $38.7 \%$ (최소 0에서 최대 37 개), 3 시수가 $54.2 \%$ (최소 0에서 최대 29개)로 대학교와전문대에 비하여 2 학점 교과목의 비율이 다소 높은 것을 확 인할 수 있으나 학교별로 매우 상이하여 직접적인 비교는 어려웠다.

각 학제별 전공 교과목 수업에 대해 전임 및 비전임이 담당하는 비율을 Figure 7에 제시하였으며 각 학교별 현황을 Appendix 9에 제시하였다. 전임교원의 수업에는 정년 및 비정년 전임교원이 담당 하는 교과목이 포함되었으며, 비전임교원의 수업에는 시간강사가 담당하는 교과목도 포함되었다. 대학교의 경우 전체 교과목에 대

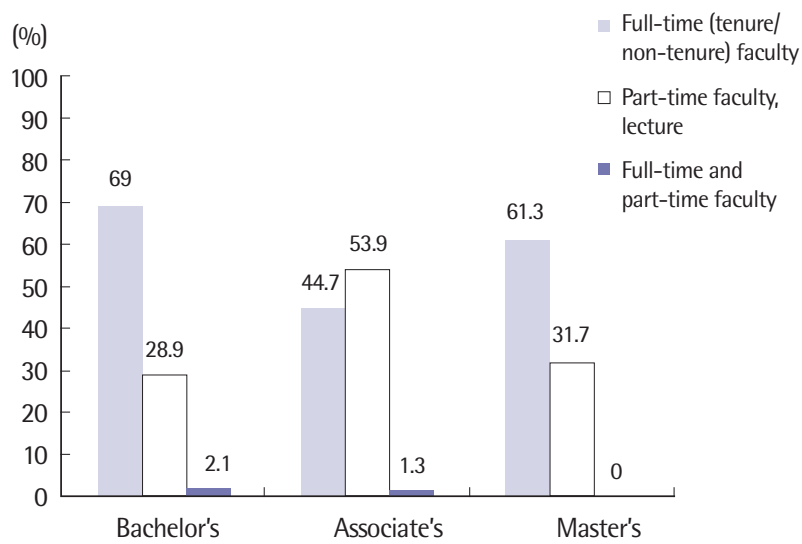

Figure 7. Distribution of faculty employment types.

한 전임교원의 비율이 평균 $69.0 \%$ 로, 가장 낮은 학교는 $42.9 \%$ 에서 가장 높은 학교는 $100 \%$ 였다. 전문대의 경우 평균 $44.7 \%$ 로, 가장 낮 은 학교는 $31.4 \%$ 였으며 가장 높은 학교는 $51.9 \%$ 였다. 대학원의 경 우 평균 $61.3 \%$ 로 가장 낮은 학교는 $4.7 \%$ 였으며, 가장 높은 경우는 $100 \%$ 로서 학교마다 전임 및 비전임의 강의 담당 비율에 있어서 차 이가 많았다. 한편 각 학교에서 개설되는 전체 교과목에 대한 전임 교원 비율을 살펴보면 대학교가 전문대에 비하여 전체적으로 높은 것을 알 수 있었다. 이는 각 대학 내 전임교수 수의 차이와 더불어 전문대의 경우, 언어재활사 양성을 위한 교과목 이외의 교과목을 전공 교과목으로 개설하여 운영하고 있기 때문인 것으로 보인다. 분반으로 인해 전임 및 비전임이 공동으로 담당하는 과목도 대학 교에서 $2.1 \%$, 전문대에서 $1.3 \%$ 의 비율로 나타났다.

\section{언어재활전공 교육과정에 대한 수요}

'대학 여건에 따라 전공 이수학점을 줄여야 할 경우 어떠한 선택 을 할 것인가?'라는 설문 문항에 대해 '전공 교과목의 학점을 줄이 고 전공 교과목 수를 유지하겠다'라고 응답한 경우는 대학교 11개 교 중 7 개교, 전문대 4 개교 중 4 개교 모두, 대학원은 총 13 개교, 15 개 프로그램으로 나타나, 학점을 줄이더라도 전공 교과목 수를 유 지하고자 하는 응답이 전체 응답의 $70.27 \%$ 를 차지하였다.

'전공 교과목의 학점을 유지하고 중요도가 낮은 교과목을 개설 하지 않겠다'라고 응답한 대학교는 4 개교, 대학원은 5 개교로 $24.32 \%$ 의 응답률을 보였다. 대학교에서 상대적으로 중요도가 낮다고 언급 한 교과목들은 '재활학', '심리학개론', '특수교육학' 등이었는데, 이 교과목들은 기초 교과목으로 현장의 요구와 직접적인 관련성이 낮 고 교양 과목이나 인터넷 강의로 개설할 수 있으므로 타 교과목의 학점을 줄이기보다는 이러한 교과목들을 개설하지 않을 것이라 응 답하였다. 대학교 졸업학점 축소 등으로 인하여 기존에는 독립 교 
과목으로 운영하였던 ‘마비말장애’, ‘뇌성마비 언어재활', '삼킴장 애'와 같은 교과목들을 개설하지 않고 '신경언어장애' 수업에서 보 완하는 대학교도 있는 것으로 나타났다. 대학원에서는 상대적으로 중요도가 낮은 교과목으로 '재활학'을 가장 많이 응답(4개교)하였 으며, ‘구개파열 언어재활', '문제행동 언어재활', ‘지적장애 언어재 활'은 2개교에서 응답하였다. 이 외에도 ‘노화와 의사소통' '다문화 의사소통', '언어학', '청각학', '학습장애 언어재활', '의사소통장애 상담, '뇌성마비 언어재활', '심리학개론' 등의 교과목을 상대적으 로 중요도가 낮은 교과목으로 언급하였으며, 그 이유로는 '기초 교 과목이기 때문, '강의할 적절한 강사가 부족하기 때문' '타 과목과 중복 내용이 많기 때문' 등의 이유와 더불어 '선택 교과목이 너무 많으므로 선택과목 수를 줄이고 타 학과에서 들을 수 있는 교과목 들은 개설하지 않는 것이 바람직하다'는 의견을 제시하였다. 설문 에 응답한 전문대는 모두 전공 교과목 수를 유지하겠다고 응답하 였으므로 상대적으로 중요도가 낮아 개설하지 않을 것이라는 교 과목 목록을 제시하지는 않았다.

개설을 희망하기는 하나 여러 이유로 미처 개설하지 못한 교과 목들에 대하여 대학교에서는 '의사소통장애 연구방법론', '언어재 활 교재개발', '언어재활 사례 연구', '구개열 언어재활', '다문화 의 사소통장애', '말과학' 등을 개설하지 못하였고 그 이유로는 수강인 원이 10 명 미만이어서 혹은 대학 내 개설과목 수의 제한으로 인하 여 개설하지 못하였다는 응답이 있었다. 개설하지 못한 교과목은 '격년으로 개설하거나 계절학기에 개설할 계획'이라고 응답하였으 며, '적절한 강사를 구하지 못하여 개설하지 못하였다'고 하는 응답 이 대다수였다. 전문대에서는 1 개교에서 '보완대체의사소통' '청각 학'과 같은 교과목을 2017학년도에 개설하고자 하였으나 '학과의 총 개설학점 제한으로 인하여 개설하지 못하였다'고 응답하였다. 대학원에서는 '의사소통장애 상담', '말과학', '보완대체의사소통', '청각장애 언어재활', '문제행동 언어재활', '재활학', '노화와 의사소 통' 등을 응답하였으며, 미개설 사유로 '적절한 강사를 구하지 못함' 이 가장 높은 응답률을 보였고, 그 외에도 '타 교과목과 중복된 내 용이 있기 때문'과 '대학 내 강의 개설 교과목 수 제한 때문'이라고 응답하였다.

'미래에 개설될 필요가 있다고 판단되는 교과목'에 대하여 다양 한 응답이 나왔는데, 대학교에서는 '노화와 의사소통' '보완대체의 사소통', '다문화 언어재활', '학령기 언어재활', '언어재활 교재 및 교구개발과 활용, '의사소통장애 임상세미나', 'AAC와 IT 활용 언 어재활' 등뿐만 아니라상담 관련 교과목 등에 대한 응답도 있었다. 미래 언어재활사 양성에 필요한 교과목에 대하여 응답한 전문대는 없었다. 대학원에서는 '보완대체의사소통', '한국어문법, '국문학',
'의사소통장애 임상세미나', '영유아 평가 및 중재', '청각장애 진단 및 평가', '학령기 언어치료', '노인인지언어재활', ‘언어병리학과 테 크놀로지', '언어재활 공학세미나' 등을 응답하였다. 이는 언어 전반 에 대한 이해 및 우리 문법에 대한 정확한 분석의 필요성과 함께, 노 령화를 이해하고 그와 관련된 교과목 개설, 그리고 4차 산업혁명에 부합하는 교육 추진과 융복합 교과과정에 대한 방향성을 제시하 고자 함이 반영된 것이라 할 수 있다. 대학원과 대학교 두 학제 모두 에서 미래 언어재활사 양성에 필요한 교과목 키워드로서 '학령기', '노인(노화)', '보완대체의사소통', 'IT/테크놀로지’ 등을 포함하였다.

\section{논의 및 결론}

본 연구에서는 언어재활전공이 개설되어 있는 대학의 학제별 교 과과정을 살펴보았다. 전체 교과목 정보, 이론 및 실습 과목, 교과 목의 학점 및 시수 분포 등의 현황을 학제별로 분석하고 미래 교과 목에 대한수요도 살펴보았다.

언어재활전공에서 대학 교과과정 내 이루어지는 실무교육은 학 생들의 전문성에 매우 중요한 역할을 한다(Kim \& Yoo, 2011; Kim et al., 2015). 이에 따라 언어재활사 시험 요건으로서도 언어재활현 장실무, 언어재활관찰, 언어진단실습 및 언어재활실습 등의 교과목 이 필수로 포함되어 있다. 언어재활 전공이 있는 모든 대학에서는 교과목 명칭은 다소 상이하나 언어재활관찰, 언어진단실습, 언어재 활실습에 해당하는 교과목을 개설하여 운영하고 있었다. 그러나 Appendices 7, 8에 제시한 바와 같이 분반이 없는 형태부터 많게는 5 분반까지 다양한 형태로 운영됨을 알 수 있었으며 각 강의에 포함 된 인원의 편차도 상당히 큰 것을 확인하였다. 특히 언어치료 실습 교육에 있어 가장 중요한 요소 중 한 가지가 '감독자 요인'이라 할 수 있는 만큼(Yun et al., 2010), 한 감독자가 담당하는 실습 학생의 수 는 실습 수업의 질을 좌우할 수 있는 요인이다. 선행연구를 살펴보 면, 임상실습 관찰자 및 감독자 1 인당 담당 학생수가 10 명 이내의 소규모 강의로 개설하는 학교로부터 많게는 26 명 이상의 학생을 담당하는 학교까지 다양하였다(Yun et al., 2010). 그러나 언어재활 사의 전문성 향상을 위해서는 협회 및 학회 차원에서 감독자 1 인당 적절한 담당 학생 수를 각 대학에 권장함으로써 언어재활사의 실 무역량 발전과 언어재활전공 대학 내 실습교육 발전에 도움이 꾀할 수 있을 것이다.

각 대학에서 개설된 전체 교과목에 대한 담당 전임교원 비율을 살펴본 결과, 대학교가 전문대에 비하여 전체적으로 전임교원이 교 과목을 담당하여 강의하는 비율이 높은 것을 확인할 수 있었다. 그 러나 이는 전문대의 경우 언어재활전공 관련 교과목을 전임교원이 
담당하지 않는다기 보다는 보육교사, 미술치료사 등의 자격증 취득 을 위한 교과목의 담당교수가 대부분 비전임인 것이 영향을 미친 것으로 보인다. 언어재활 이외의 자격증 과정을 교과과정에 편성하 는 것은 매년 천여 명이 넘는 언어재활사가 배출되고 있는 현 시점 에서 전문대 졸업생의 취업률을 높이고 다양한 취업처를 모색하기 위한 현실적인 묘안이기는 하나, 언어재활사로서의 학문적 역량을 충분히 갖추도록 양성할 수 있을지에 대한 고민도 드는 바이다.

언어재활전공의 교육과정 수요에 대하여 살펴본 결과, 졸업 이수 학점을 줄여야 할 경우 대부분의 대학들이 개설 교과목 수를 줄이 기보다는 '교과목의 학점이나 시수를 줄이는 선택을 하겠다'라고 응답하였다. 대학의 여건에 따라 교과목을 줄여야 하는 상황이 발 생할 경우에는 교양과목과 같이 타 학과에서 개설할 수 있는 기초 교과목들을 개설하지 않겠다는 의견이 많았다. 이는 언어재활사가 이수해야 하는 교과목 수가 적지 않지만 실무능력 배양을 위하여 다양한 교과목들을 개설하고자 하는 의지가 반영된 응답으로 보 인다. 그러나 시수가 줄여진 상태에서 교과목 수가 유지된다면 해 당 이론 및 실제에 대한 교육이 충분히 이루어지지 않을 수 있기 때 문에 적은 시수로도 지식 교육이 가능한 교수법을 고안하여 활용 할 필요가 있다. 한편, 미래의 언어재활사 양성에 필요한 교과목으 로서는 4 차산업혁명시대를 이해하고 다양한 테크놀로지와 언어치 료를 융합할 수 있는 교과목 및 학령기와 노령화에 대한 관심을 반 영한 교과목들을 제시하고 있는 것으로 나타났다.

연구의 제언으로는 첫째, 본 연구에서는 대학원의 교과과정 분 석 시 일반대학원과 특수대학원 등 대학원의 유형에 따라 구분하 지 않고 분석하였다. 추후에는 각 대학원의 특성을 구분하여 분석 을 실시해 본다면 언어재활전공 대학원 교과과정의 기초정보로 더 욱 의미 있는 자료가 될 수 있을 것이다. 둘째, 본 연구는 2015년부 터 2017년까지 각 대학별 교육과정을 회수하였으나 연도별 비교분 석은 실시하지 않았다. 이는 대부분의 학교에서 개설한 교과목 명 칭 및 교과 정보에 큰 변화가 나타나지 않았기 때문이다. 그러나 국 내 대학에서 졸업을 위해 요구되는 전공교육의 요건이 급변하고 있
는 만큼 추후 연구에서는 전체 교과목 수, 학점, 시수 등에 대한 변 화가 나타나는지 그 추이를 살펴보는 것도 의미가 있으리라 판단된 다. 셋째, 본 연구에서 사용한 설문지는 각 대학의 학과 대표(예: 학 과장)가 응답한 경우가 대부분이며, 특히 2차 설문지에 포함된 교 육과정 수요에 대한 응답은 학과 대표의 의견이 중점적으로 반영되 었을 확률이 높은 것으로 판단된다. 따라서, 향후에는 언어재활전공 영역 또는 학과에 재직 중인 전체 교수들을 대상으로 설문 조사가 이루어질 필요성이 있다고 사료된다. 넷째, 언어재활전공 대학의 전 공선택 과목의 개설/폐설 요건으로 중요시 여기는 사항에 대해좀더 심층적으로 분석된다면 더욱 의미 있는 자료가 될 수 있을 것이다.

\section{REFERENCES}

Kim, S. J., \& You, Y. J. (2011). Current factors contributing to professionalism in speech and language pathology. Korean Journal of Communication Disorders, 16, 397-407.

Kim, Y. T., Choi, H., Kim, M. J., Kim, J., Jeon, H., Kim, T., \& Kang, M. (2015). Speech-language pathologists' perceptions of the importance, difficulty, and frequency of their duties and tasks. Communication Sciences \& Disorders, 20, 97-105.

Kim, Y. T., Kim, J., Jeon, H. S., Choi, H., Kim, M. J., \& Kim. T. (2013). Job analysis of speech-language pathologist. Seoul: Korea Health Personnel Licensing Examination Institute.

Lee, J. H., Lee, J. Y., Cho, S. J., Park, S. I., Kim, J. D., Park, M. H., ... \& Kim, J. (2017). A survey of educational environment for the accreditation of audiology and hearing sciences education. Audiology and Speech Research, 13, 193-208

Yun, H. R., Kwon, S. B., Kim, S. J., Pae, S., Shin, M. S., \&. Hwang, M. (2010). Study on the status of curriculum and development of certification standard for speech-language pathology. Journal of Speech \& Hearing Disorders, $15,271-284$. 
Hyun Rin Park, et al. • Curriculum in Speech-Language Pathology Programs

Appendix 1. 2차 설문지 내용

대학명: 대학교

1. 대학 여건에 따라 전공 이수 학점을 줄여야 한다면, 아래 중 어떠한 경우를 선택하시겠습니까?

(1) 전공 교과목의 학점을 줄이고 전공 교과목 수를 유지함

(2) 전공 교과목의 학점을 줄이지 않고 중요도가 낮은 과목을 개설하지 않음

(3) 기타 [직접기입: ]

1-1. 위의 문항에서 (2)를 선택한 경우에만 응답해 주시기 바랍니다. 중요도가 낮은 과목에 어떠한 교과목이 포함될 수 있는지 3과목 이상 작성해 주시기 바랍니다.

1-2. 1-1에서 위와 같은 교과목을 선택한 이유를 자유롭게 기술해 주시기 바랍니다.

2. 2017학년도 1,2학기에 개설하고자 하였으나 여건 상 개설하지 못한 교과목이 있습니까?

(1) 아니요

(2) 네

2-2. 개설하지 못한 이유는 무엇인지 자유롭게 기술하여 주시기 바랍니다.

3. 미래 언어치료사 양성에 필요한 교과목이 있다면 1과목 이상 작성해 주시기 바랍니다.

3-1. 3번에서 위와 같은 교과목을 선택한 이유를 자유롭게 기술해 주시기 바랍니다. 
Appendix 2. 대학별 전공 교과목의 총 개수와 학년별 교과목 분포(2017년 기준)

\begin{tabular}{|c|c|c|c|c|c|c|}
\hline & $\overline{\bar{\lambda}}$ & & & 교과목 수(\% & & \\
\hline & ᄀ正 & 1학년 & 2학년 & 3학년 & 4학년 & 전체 \\
\hline 학부 & A & $4(12.5)$ & $8(25)$ & $10(31.3)$ & 10 (31.3) & 32 (100) \\
\hline & B & $7(20)$ & $8(22.9)$ & $10(28.6)$ & $10(28.6)$ & 35 (100) \\
\hline & $C$ & $6(16.2)$ & $9(24.3)$ & $11(29.7)$ & $11(29.7)$ & 37 (100) \\
\hline & D & $6(17.1)$ & $7(20)$ & $14(40)$ & $8(22.9)$ & 35 (100) \\
\hline & $E$ & $8(20)$ & $9(22.5)$ & $12(30)$ & $11(27.5)$ & 40 (100) \\
\hline & $\mathrm{F}$ & $0(0)$ & $10(35.7)$ & $11(39.3)$ & $7(25)$ & $28(100)$ \\
\hline & G & 4 (11.1) & $10(27.8)$ & 12 (33.3) & $10(27.8)$ & 36 (100) \\
\hline & $\mathrm{H}$ & $4(13.8)$ & $10(34.5)$ & 8 (27.6) & $7(24.1)$ & 29 (100) \\
\hline & I & $3(7.9)$ & $10(26.3)$ & $14(36.8)$ & $11(28.9)$ & 38 (100) \\
\hline & J & $6(14)$ & $11(25.6)$ & $12(27.9)$ & 14 (32.6) & $43(100)$ \\
\hline & K & $7(24.1)$ & $7(24.1)$ & $10(34.5)$ & $5(17.2)$ & $29(100)$ \\
\hline & $\mathrm{L}$ & $6(17.6)$ & $10(29.4)$ & $12(35.3)$ & $6(17.6)$ & 34 (100) \\
\hline & $\mathrm{M}$ & $4(12.5)$ & $9(28.1)$ & $11(34.4)$ & $8(25)$ & 32 (100) \\
\hline & $\mathrm{N}$ & $4(13.8)$ & $9(31)$ & 8 (27.6) & $8(27.6)$ & 29 (100) \\
\hline & $\mathrm{O}$ & $4(13.8)$ & $7(24.1)$ & $9(31)$ & $9(31)$ & 29 (100) \\
\hline & $P$ & $6(17.1)$ & $10(28.6)$ & 10 (28.6) & $9(25.7)$ & 35 (100) \\
\hline 전문학부 & A & $6(17.1)$ & $13(37.1)$ & $16(45.7)$ & $0(0)$ & 35 (100) \\
\hline & B & 14 (31.1) & 15 (33.3) & 15 (33.3) & $0(0)$ & $45(97.8)^{a}$ \\
\hline & $C$ & $11(28.9)$ & $13(34.2)$ & $14(36.8)$ & $0(0)$ & 38 (100) \\
\hline & D & $13(30.2)$ & 15 (34.9) & 15 (34.9) & $0(0)$ & $43(100)$ \\
\hline & $E$ & $11(28.2)$ & 14 (35.9) & 14 (35.9) & $0(0)$ & 39 (100) \\
\hline & $\mathrm{F}$ & $13(31)$ & 15 (35.7) & 14 (33.3) & $0(0)$ & 42 (100) \\
\hline & G & $13(27.7)$ & 15 (31.9) & $13(27.7)$ & $6(12.8)$ & 47 (100) \\
\hline & $\mathrm{H}$ & $15(28.8)$ & 15 (28.8) & $14(26.9)$ & $8(15.4)$ & $52(100)$ \\
\hline
\end{tabular}

이수 학년 구분 없는 교과목 1개. 
Hyun Rin Park, et al. • Curriculum in Speech-Language Pathology Programs

Appendix 3. 대학원별 전공 교과목 개수(2017년 기준)

\begin{tabular}{|c|c|}
\hline 학교 & 전공 교과목 수 \\
\hline A & 24 \\
\hline B & 21 \\
\hline C & 14 \\
\hline D & 6 \\
\hline E & 19 \\
\hline $\mathrm{F}$ & 12 \\
\hline G & 37 \\
\hline $\mathrm{H}$ & 29 \\
\hline I & 27 \\
\hline J & 34 \\
\hline K & 11 \\
\hline L & 22 \\
\hline M & 17 \\
\hline N & 26 \\
\hline $\mathrm{O}$ & 11 \\
\hline$P$ & 21 \\
\hline Q & 17 \\
\hline $\mathrm{R}$ & 12 \\
\hline$S$ & 6 \\
\hline
\end{tabular}


Appendix 4. 대학별 전공필수와 전공선택 교과목 현황 및 이론과 실습 교과목 현황

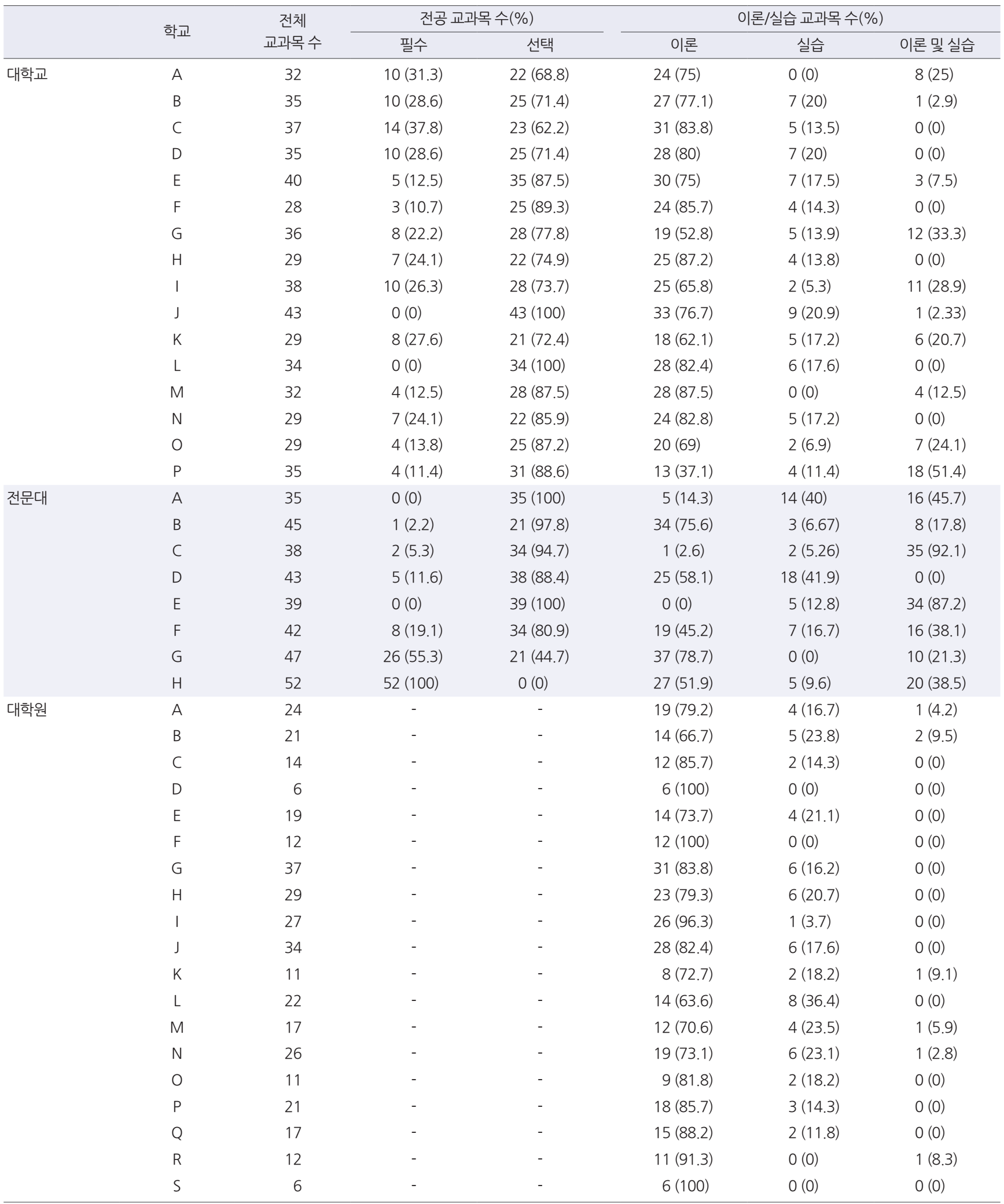


Appendix 5. 대학별 교과목의 분반 현황 및 상세 내역

\begin{tabular}{|c|c|c|c|}
\hline & 학교 & 분반수 & 교과목 명칭 \\
\hline \multirow[t]{23}{*}{ 대학교 } & A & 2분반 & 언어재활실습 I, 언어재활실습 II \\
\hline & B & 3분반 & 언어재활심화실습, 언어진단실습, 언어재활실습 \\
\hline & \multirow[t]{3}{*}{$\mathrm{D}$} & 2분반 & $\begin{array}{l}\text { 언어재활관찰, 지적장애언어재활, 의사소통장애진단평가세미나, 자폐범주성장애언어재활, 언어발달장애, 음성장애, } \\
\text { 신경언어장애, 언어발달, 한국어학, 조음음운장애, 청각장애언어재활, 발달심리학, 심리운동과 신체경험, 다문화와의사소통, } \\
\text { 심리학개론, 의사소통장애개론, 특수교육학 }\end{array}$ \\
\hline & & 3분반 & 언어진단심화실습, 언어재활심화실습 \\
\hline & & 4분반 & 언어진단실습, 언어재활실습 \\
\hline & \multirow[t]{3}{*}{$\mathrm{E}$} & 2분반 & 청각치료실습 I , 임상재활관찰, 청각치료실습 II, 언어임상진단실습, 청각치료실습 II \\
\hline & & 4분반 & ○길라잡이 \\
\hline & & 5분반 & 언어재활실습 \\
\hline & \multirow[t]{2}{*}{$\mathrm{F}$} & 2분반 & 언어재활관찰, 언어진단실습 \\
\hline & & 4분반 & 언어진단실습, 언어재활실습 \\
\hline & \multirow[t]{3}{*}{ G } & 2분반 & 심화언어재활실습, 언어재활관찰 \\
\hline & & 3분반 & 언어재활실습 \\
\hline & & 4분반 & 언어진단실습 \\
\hline & $\mathrm{H}$ & 3분반 & 언어재활실습 I, 언어재활실습 || \\
\hline & \multirow[t]{3}{*}{1} & 2분반 & $\begin{array}{l}\text { 행동수정, 학습장애언어재활, Capstone Design, 의사소통장애진단평가 및 실습, 일반청각평가이론및실습, 언어재활관찰 및 } \\
\text { 실습, 특수청각평가 이론 및 실습 }\end{array}$ \\
\hline & & 3분반 & 보청기 인공와우 실습, 청능재활실습 \\
\hline & & 4분반 & 언어진단실습 I , 언어진단실습 II, 언어재활실습 I , 언어재활실습 II \\
\hline & K & 2분반 & 언어재활실습 I , 언어재활실습 II, 언어진단실습 I , 언어진단실습 II \\
\hline & $\mathrm{L}$ & 3분반 & 언어재활실습 | , 언어재활실습 || \\
\hline & N & 5 분반 & 언어진단실습, 언어재활실습 \\
\hline & O & 2분반 & 의사소통장애개론, 언어기관해부생리, 말과학, 청각학개론, 언어재활실습 I , 언어재활실습 II \\
\hline & \multirow[t]{2}{*}{$\mathrm{P}$} & 2분반 & 언어재활관찰, 언어재활실습 \\
\hline & & 3분반 & 언어진단실습스튜디오, 특수교육학 \\
\hline \multirow[t]{8}{*}{ 전문대 } & \multirow[t]{2}{*}{ B } & 2분반 & 4분반 교과목 외 전체 교과목 \\
\hline & & 4분반 & 언어재활관찰, 언어진단실습, 언어재활실습 \\
\hline & \multirow[t]{2}{*}{ C } & 2분반 & 언어재활관찰 \\
\hline & & 4분반 & 언어재활실습, 언어진단실습 \\
\hline & $\mathrm{D}$ & 2분반 & 의사소통장애개론, 말 언어기관 해부 및 생리, 의사소통장애 진단 및 평가, 언어진단실습, 언어재활관찰, 언어재활실습 \\
\hline & $\mathrm{F}$ & 2분반 & 심화언어진단실습, 언어재활관찰, 언어진단실습, 심화언어재활실습, 언어재활실습 \\
\hline & G & 2분반 & 특수아행동수정, 언어재활관찰, 조음음운장애치료, 언어재활실습 \\
\hline & $\mathrm{H}$ & 2분반 & 언어진단실습, 언어재활관찰, 언어재활실습 \\
\hline \multirow[t]{13}{*}{ 대학원 } & A & 2분반 & 언어진단실습 I , 언어진단실습 II, 언어치료실습, 언어발달장애 \\
\hline & G & 2분반 & 언어진단실습, 언어치료관찰, 언어치료실습, 언어치료실습, 언어발달장애 I , 언어발달장애 II , 언어치료현장실무 \\
\hline & $\mathrm{H}$ & 2분반 & 언어치료실습 \\
\hline & I & 2분반 & 개별연구지도 \\
\hline & \multirow[t]{2}{*}{ K } & 2분반 & 언어발달장애 \\
\hline & & 3분반 & 언어진단실습, 언어재활치료 \\
\hline & \multirow[t]{2}{*}{$\mathrm{P}$} & 2분반 & 언어재활실습 \\
\hline & & 3분반 & 언어진단실습 \\
\hline & \multirow[t]{2}{*}{ Q } & 2분반 & 언어재활현장실무 \\
\hline & & 3분반 & 사례연구 \\
\hline & \multirow[t]{3}{*}{$\mathrm{R}$} & 2분반 & 의사소통장애개론, 말장애연구 \\
\hline & & 3분반 & 언어장애연구 \\
\hline & & 4분반 & 논문연구 | , 논문연구|| \\
\hline
\end{tabular}


Appendix 6. 대학별 전공 교과목의 학점 분포 현황

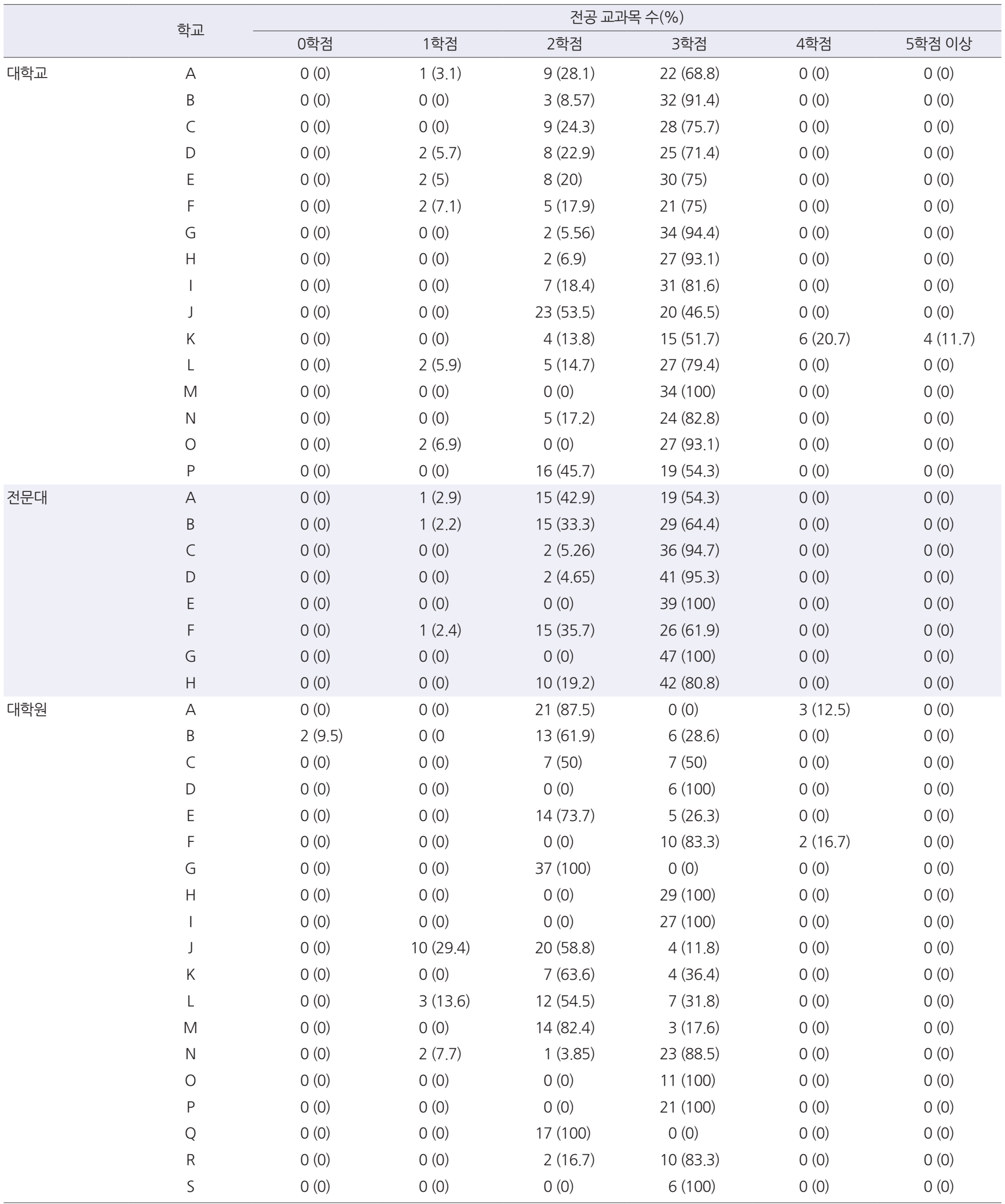

대학교 K대학 5 학점 교과목 4개(13.8\%), 대학원 B대학 0학점 교과목 2개(9.5\%). 
Appendix 7. 학제별 전공 교과목의 시수 분포 현황(대학)

\begin{tabular}{|c|c|c|c|c|c|c|c|}
\hline & \multirow{2}{*}{ 학교 } & \multicolumn{6}{|c|}{ 전공 교과목 수(\%) } \\
\hline & & 1시수 & 2시수 & 3시수 & 4시수 & 5시수 & 6시수 이상 \\
\hline \multirow[t]{16}{*}{ 대학교 } & A & $1(3.1)$ & $9(28.1)$ & $16(50)$ & $6(18.8)$ & $0(0)$ & $0(0)$ \\
\hline & B & $0(0)$ & $3(8.6)$ & $28(80)$ & $4(11.4)$ & $0(0)$ & $0(0)$ \\
\hline & $C$ & $0(0)$ & $0(0)$ & $33(89.2)$ & $4(10.8)$ & $0(0)$ & $0(0)$ \\
\hline & $\mathrm{D}$ & $2(5.7)$ & $8(22.9)$ & $21(60)$ & $4(11.4)$ & $0(0)$ & $0(0)$ \\
\hline & $E$ & $2(5)$ & $7(17.5)$ & $21(52.5)$ & $4(10)$ & $0(0)$ & $6(15)$ \\
\hline & $\mathrm{F}$ & $2(7.1)$ & $1(3.6)$ & $21(75)$ & $4(14.3)$ & $0(0)$ & $0(0)$ \\
\hline & G & $0(0)$ & $0(0)$ & 19 (52.8) & 14 (38.9) & $0(0)$ & $3(8.3)$ \\
\hline & $\mathrm{H}$ & $0(0)$ & $2(6.9)$ & 27 (93.1) & $0(0)$ & $0(0)$ & $0(0)$ \\
\hline & I & $0(0)$ & $1(2.6)$ & $25(65.8)$ & $9(23.7)$ & $1(2.6)$ & $2(5.3)$ \\
\hline & J & $0(0)$ & $3(6.9)$ & $36(83.7)$ & $4(9.3)$ & $0(0)$ & $0(0)$ \\
\hline & K & $0(0)$ & $4(13.8)$ & $15(51.7)$ & $6(20.7)$ & $2(6.9)$ & $2(6.9)$ \\
\hline & $L$ & $0(0)$ & $3(8.8)$ & $27(79.4)$ & $4(11.8)$ & $0(0)$ & $0(0)$ \\
\hline & M & $0(0)$ & $0(0)$ & 34 (106) & $0(0)$ & $0(0)$ & $0(0)$ \\
\hline & $\mathrm{N}$ & $0(0)$ & $0(0)$ & $22(75.9)$ & $7(24.1)$ & $0(0)$ & $0(0)$ \\
\hline & $\mathrm{O}$ & $2(6.9)$ & $0(0)$ & 27 (93.1) & $0(0)$ & $0(0)$ & $0(0)$ \\
\hline & $P$ & $0(0)$ & $3(8.6)$ & $31(88.6)$ & $2(5.7)$ & $0(0)$ & $0(0)$ \\
\hline \multirow[t]{8}{*}{ 전문대 } & $A$ & $1(2.9)$ & 15 (42.9) & $19(54.3)$ & $0(0)$ & $0(0)$ & $0(0)$ \\
\hline & B & $1(2.2)$ & $12(26.7)$ & $21(46.7)$ & $11(24.4)$ & $0(0)$ & $1(2.2)$ \\
\hline & $C$ & $1(2.6)$ & $2(5.3)$ & 35 (92.1) & $0(0)$ & $0(0)$ & $0(0)$ \\
\hline & $\mathrm{D}$ & $1(2.3)$ & $1(2.3)$ & 40 (93) & $1(2.33)$ & $0(0)$ & $0(0)$ \\
\hline & $E$ & $0(0)$ & $0(0)$ & 39 (100) & $0(0)$ & $0(0)$ & $0(0)$ \\
\hline & $\mathrm{F}$ & $1(2.4)$ & $13(31)$ & $23(54.8)$ & $3(7.1)$ & $0(0)$ & $2(4.8)$ \\
\hline & G & $1(2.1)$ & $0(0)$ & 37 (78.7) & 9 (19.1) & $0(0)$ & $0(0)$ \\
\hline & $\mathrm{H}$ & $0(0)$ & $3(5.8)$ & 38 (73.1) & $7(13.5)$ & $0(0)$ & $4(7.6)$ \\
\hline
\end{tabular}

Appendix 8. 학제별 전공 교과목의 시수 분포 현황(대학원)

\begin{tabular}{|c|c|c|c|c|c|c|c|}
\hline & \multirow{2}{*}{ 학교 } & \multicolumn{6}{|c|}{ 전공 교과목 수(\%) } \\
\hline & & 0시수 & 1시수 & 2시수 & 3시수 & 4시수 & 5시수 이상 \\
\hline \multirow[t]{19}{*}{ 대학원 } & A & $0(0)$ & $0(0)$ & $21(87.5)$ & $0(0)$ & $3(12.5)$ & $0(0)$ \\
\hline & B & $2(9.5)$ & $0(0)$ & $12(57.1)$ & $7(33.3)$ & $0(0)$ & $0(0)$ \\
\hline & C & $0(0)$ & $0(0)$ & $6(42.9)$ & $7(50)$ & $1(7.1)$ & $0(0)$ \\
\hline & D & $0(0)$ & $0(0)$ & $0(0)$ & $6(100)$ & $0(0)$ & $0(0)$ \\
\hline & $\mathrm{E}$ & $0(0)$ & $0(0)$ & $14(73.7)$ & $5(26.3)$ & $0(0)$ & $0(0)$ \\
\hline & $\mathrm{F}$ & $2(16.7)$ & $0(0)$ & $0(0)$ & $10(83.3)$ & $0(0)$ & $0(0)$ \\
\hline & G & $0(0)$ & $0(0)$ & $37(100)$ & $0(0)$ & $0(0)$ & $0(0)$ \\
\hline & $\mathrm{H}$ & $0(0)$ & $0(0)$ & $0(0)$ & $29(100)$ & $0(0)$ & $0(0)$ \\
\hline & I & $0(0)$ & $0(0)$ & $0(0)$ & 27 (100) & $0(0)$ & $0(0)$ \\
\hline & J & $0(0)$ & $10(29.4)$ & $20(58.8)$ & $4(11.8)$ & $0(0)$ & $0(0)$ \\
\hline & K & $0(0)$ & $0(0)$ & 7 (63.6) & $4(36.4)$ & $0(0)$ & $0(0)$ \\
\hline & $\mathrm{L}$ & $0(0)$ & $3(13.6)$ & $12(54.5)$ & $7(31.8)$ & $0(0)$ & $0(0)$ \\
\hline & M & $0(0)$ & $0(0)$ & $14(82.4)$ & $3(17.6)$ & $0(0)$ & $0(0)$ \\
\hline & $\mathrm{N}$ & $0(0)$ & $2(7.7)$ & $1(3.8)$ & $23(88.5)$ & $0(0)$ & $0(0)$ \\
\hline & 0 & $0(0)$ & $0(0)$ & $0(0)$ & $9(81.8)$ & $0(0)$ & $2(18.2)$ \\
\hline & $\mathrm{P}$ & $0(0)$ & $0(0)$ & $0(0)$ & $18(85.7)$ & $0(0)$ & $3(14.3)$ \\
\hline & Q & $0(0)$ & $0(0)$ & $16(94.1)$ & $0(0)$ & $1(5.9)$ & $0(0)$ \\
\hline & $\mathrm{R}$ & $0(0)$ & $0(0)$ & $2(16.7)$ & $10(83.3)$ & $0(0)$ & $0(0)$ \\
\hline & $S$ & $0(0)$ & $0(0)$ & $0(0)$ & 6 (100) & $0(0)$ & $0(0)$ \\
\hline
\end{tabular}


Appendix 9. 학제별 전임 및 비전임의 교과목 담당 비율

\begin{tabular}{|c|c|c|c|c|c|}
\hline & \multirow{2}{*}{ 학교 } & \multirow{2}{*}{$\begin{array}{c}\text { 전체 } \\
\text { 교과목 수 }\end{array}$} & \multicolumn{3}{|c|}{ 담당 교과목 수(\%) } \\
\hline & & & 전임 & 비전임 & 전임/비전임 공동 \\
\hline \multirow[t]{16}{*}{ 대학교 } & A & 32 & $22(68.8)$ & $10(31.2)$ & $0(0)$ \\
\hline & $B$ & 35 & 35 (100) & $0(0)$ & $0(0)$ \\
\hline & C & 37 & $21(56.8)$ & $16(43.2)$ & $0(0)$ \\
\hline & $\mathrm{D}$ & 35 & $24(68.6)$ & $7(20)$ & $4(11.4)$ \\
\hline & $E$ & 40 & $26(65)$ & $11(27.5)$ & $3(7.5)$ \\
\hline & $\mathrm{F}$ & 28 & $12(42.9)$ & $14(50)$ & $2(7.1)$ \\
\hline & G & 36 & $22(61.1)$ & $13(36.2)$ & $1(2.7)$ \\
\hline & $\mathrm{H}$ & 29 & $18(62.1)$ & $11(37.9)$ & $0(0)$ \\
\hline & I & 38 & $27(71.1)$ & 7 (23.6) & $2(5.3)$ \\
\hline & J & 43 & $32(74.4)$ & $11(25.6)$ & $0(0)$ \\
\hline & K & 29 & $14(48.3)$ & $15(51.7)$ & $0(0)$ \\
\hline & $\mathrm{L}$ & 34 & $27(79.4)$ & 7 (20.6) & $0(0)$ \\
\hline & M & 32 & $16(50)$ & $16(50)$ & $0(0)$ \\
\hline & $\mathrm{N}$ & 29 & $20(69)$ & $9(31)$ & $0(0)$ \\
\hline & $\mathrm{O}$ & 29 & $25(87.2)$ & $4(13.8)$ & $0(0)$ \\
\hline & $\mathrm{P}$ & 35 & 35 (100) & $0(0)$ & $0(0)$ \\
\hline \multirow[t]{8}{*}{ 전문대 } & A & 35 & $11(31.4)$ & $24(69.6)$ & $0(0)$ \\
\hline & B & 45 & $22(48.9)$ & $23(51.1)$ & $0(0)$ \\
\hline & C & 38 & $17(44.7)$ & $17(44.8)$ & $4(10.5)$ \\
\hline & $\mathrm{D}$ & 43 & $21(48.8)$ & $22(51.2)$ & $0(0)$ \\
\hline & $E$ & 39 & $14(35.9)$ & $25(64.1)$ & $0(0)$ \\
\hline & $\mathrm{F}$ & 42 & $20(47.6)$ & $22(52.4)$ & $0(0)$ \\
\hline & G & 47 & $23(48.9)$ & $24(51.1)$ & $0(0)$ \\
\hline & $\mathrm{H}$ & 52 & $27(51.9)$ & $25(48.1)$ & $0(0)$ \\
\hline \multirow[t]{19}{*}{ 대학원 } & A & 24 & $12(50)$ & $12(50)$ & $0(0)$ \\
\hline & B & 21 & 9 (42.9) & $12(57.1)$ & $0(0)$ \\
\hline & C & 14 & $3(21.4)$ & $11(78.6)$ & $0(0)$ \\
\hline & D & 6 & $6(100)$ & $0(0)$ & $0(0)$ \\
\hline & $E$ & 19 & 19 (100) & $0(0)$ & $0(0)$ \\
\hline & $\mathrm{F}$ & 12 & $10(83.3)$ & $2(16.7)$ & $0(0)$ \\
\hline & G & 37 & $16(43.2)$ & $21(56.8)$ & $0(0)$ \\
\hline & $\mathrm{H}$ & 29 & $15(51.7)$ & $14(48.4)$ & $0(0)$ \\
\hline & I & 27 & $23(85.2)$ & $4(14.8)$ & $0(0)$ \\
\hline & $J$ & 34 & $14(41.2)$ & $20(58.8)$ & $0(0)$ \\
\hline & K & 11 & - & - & $0(0)$ \\
\hline & $\mathrm{L}$ & 22 & $5(22.7)$ & 17 (77.3) & $0(0)$ \\
\hline & M & 17 & 9 (52.9) & 8 (47.1) & $0(0)$ \\
\hline & $\mathrm{N}$ & 26 & $22(84.6)$ & 4 (15.4) & $0(0)$ \\
\hline & $\mathrm{O}$ & 11 & 10 (90.9) & $1(9.1)$ & $0(0)$ \\
\hline & $\mathrm{P}$ & 21 & $1(4.76)$ & $20(95.2)$ & $0(0)$ \\
\hline & Q & 17 & 9 (52.9) & $8(47.1)$ & $0(0)$ \\
\hline & $\mathrm{R}$ & 12 & $11(91.7)$ & $1(8.3)$ & $0(0)$ \\
\hline & $S$ & 6 & 5 (83.3) & $1(16.7)$ & $0(0)$ \\
\hline
\end{tabular}




\section{국문초록}

\section{언어재활전공 교과과정의 국내 현황 조사}

박현린 ${ }^{1}$ 황보명 ${ }^{2}$ 김향희 ${ }^{34} \cdot$ 장선아 ${ }^{5} \cdot$ 최성희 ${ }^{6} \cdot$ 김재옥 $\cdot$ 김효정8 $\cdot$ 박희준9

1광주대학교 보건복지교육대학 언어치료학과, ${ }^{2}$ 호남대학교 보건과학대학 언어치료학과, ${ }^{3}$ 연세대학교 대학원 언어병리학협동과정, ${ }^{4}$ 연세대학교 의과대학 재활의학교실 및 재활의학연구소, ${ }^{5}$ 서울대학병원 이비인후과학교실, ${ }^{6}$ 대구가톨릭대학교 바이오메디대학 언어청각치료학과, ${ }^{7}$ 강남대학교 교육대학원 언어치료교육전공, ${ }^{8}$ 고신대학교 보건복지대학 언어치료학과, ${ }^{9}$ 춘해보건대학 언어치료학과

배경 및 목적: 국내 대학에 언어재활전공이 처음 개설된 1988년을 기점으로 2018년 현재 총 50개의 대학(대학교, 전문대학, 대학원)에 서 총 87 개의 프로그램이 운영되고 있다. 이러한 양적 팽창이 이루어진 현 시점에서 각 프로그램들의 운영 현황을 살펴보고 미래를 준 비하는 노력이 필요할 것으로 판단된다. 이에 본 연구에서는 전국 대학에 개설되어 있는 언어재활전공 교과과정 현황을 분석하여 기초 자료를 제공하고 우수한 언어재활사 양성을 위한 미래의 방향 모색을 위한 초석을 마련하고자 하였다. 방법: 대학교, 전문대학, 대학원 에 언어재활전공이 개설된 학교에 대학의 기본정보, 2015년에서 2017년 사이의 전공 교과목 개설 현황, 교과과정에 대한 수요 등의 내 용이 포함된 설문지를 2 차에 걸쳐 배포하였다. 설문에 응하지 않은 학교들을 제외한 후, 1 차 설문지 내용은 총 43 개 프로그램을 대상으 로 분석하였고 2 차 설문지 내용은 총 33 개 프로그램을 대상으로 분석하였다. 결과: 세 가지 학제별 교과과정을 살펴본 결과, 대학교와 전문대학 중 언어재활사 자격 이외의 자격증 과정을 개설하고 있는 대학의 경우 개설 교과목 수가 상대적으로 많은 것으로 나타났다. 대학의 상황에 따라 분반 운영 및 전공선택과 전공필수 구분 등에 있어서 편차가 많은 것을 알 수 있었다. 대학교와 대학원 과정의 교과 과정 수요 분석에서는 학령기, 노인(노화), 보완대체의사소통, IT 등의 키워드가 공통적으로 포함된 것을 알 수 있었다. 논의 및 결론: 본 연구자료는 국내 언어재활전공의 교과과정 현황을 살펴봄과 동시에 추후 질 높은 언어재활사 양성을 위한 교과과정을 제시함에 있 어 기초 자료로서 활용되기를 기대해본다.

핵심어: 교과과정, 커리큘럼, 언어재활, 언어치료, 조사연구

본 논문은 한국언어재활사협회의 ‘인증사업단’ 용역과제로 시행된 연구이며, 2017년 11월 4일 전국언어치료학과협의회 총회에서 일부 내용 이 발표됨.

\section{참고문헌}

김수진, 유영준(2011). 언어치료사의 전문성 인식 연구. 언어청각장애연구, 16,387-407.

김영태, 김재옥, 전희숙, 최현주, 김민정, 김태우(2013). 언어재활사직무분석 연구. 서울: 한국보건의료인국가시험원.

김영태, 최현주, 김민정, 김재옥, 전희숙, 김태우, 강민경(2015). 언어재활사의 직무 중요도, 난이도, 빈도에 대한 인식. 언어청각임상연구, 20, 97-105.

윤혜련, 권순복, 김수진, 배소영, 신명선, 황민아(2010). 언어치료학과 교과과정 현황조사 및 인증기준 개발. 언어청각장애연구, 15, 271-284.

이재희, 이지영, 조수진, 박성일, 김진동, 박미혜, 신은영, 김진숙(2017). 청각학 학과인증제 교육과정 조사 연구. 청능재활, 13, 193-208. 